the water-soluble pectin fraction of heat- plus Ca-treated apples as in the other treatments. This result suggests that the increased $\mathrm{Ca}$ in the combined treatment may have different binding sites than $\mathrm{Ca}$ dips of unheated fruit and that this may contribute to the enhanced firmness measured in this treatment.

\section{Literature Cited}

Blumenkrantz, N. and G. Asboe-Hansen. 1973.

New method for quantitative determination of uranic acids. Anal. Biochem. 54:484-489.

Ferguson, LB. 1984. Calcium in plant senescence and fruit ripening. Plant, Cell \& Environ. 7:477489.

Klein, J.D. and S. Lurie. Prestorage heat treatment as a means of improving poststorage quality of apples. J. Amer. Soc. Hort. Sci. 115:265269.

Klein, J.D., S. Lurie, and R. Ben-Arie. 1990. Quality and cell wall components of 'Anna' and 'Granny Smith' apples treated with heat, calcium, and ethylene. J. Amer. Soc. Hort. Sci. 115:954-958.

Liu, F.W. 1978. Modification of apple quality by high temperature. J. Amer. Soc. Hort. Sci. 103:730-732.
Lurie, S. and J.D. Klein. 1990. Heat treatment of apples: Differential effects on physiology and biochemistry. Physiol. Plant. 78:181-186.

Poovaiah, B.W. 1986. Role of calcium in prolonging storage life of fruits and vegetables. Food Technol. 58:86-89.

Porritt, S. and P. Lidster. 1978. The effect of prestorage heating on ripening and senescence of apples during cold storage. J. Amer. Soc. Hort. Sci. 103:584-587.

SAS Institute. 1985. SAS introductory guide. 3rd ed. SAS Institute, Inc., Cary, N.C.

HORTSCIENCE 27(1):39-41. 1992.

\title{
Controlled-atmosphere Storage of Sugar Peas
}

\author{
Stacey L. Ontai \\ Department of Vegetable Crops, Mann Laboratory University of \\ California, Davis CA 95616 \\ Robert E. Paul1 \\ Department of Botany, University of Hawaii, Honolulu, HI 96822 \\ Mikal E. Saltveit, Jr. \\ Department of Vegetable Crops, Mann Laboratory, University of \\ California, Davis, CA 95616
}

Additional index words. weight loss, chlorophyll, soluble sugars, insoluble solids, soluble protein, subjective quality

Abstract. Sugar peas (Pisum sativum var. saccharatum cv. Manoa Sugar) were stored for 14 or 21 days under controlled atmospheres $(\mathrm{CA})$ of $21 \%$ or $2.4 \% \mathrm{O}_{2}$, plus $0 \%$, $2.6 \%$, or $4.7 \% \mathrm{CO}_{2}$ at 10 or $1 \mathrm{C}$. Changes in appearance, weight, and in the concentrations of chlorophyll, total soluble sugars, insoluble solids, and soluble protein wer evaluated before and after storage. After 14 days of storage at $10 \mathrm{C}$ there were minor changes in all indicators of quality under the various storage conditions, but the appearance of sugar peas was better under $\mathrm{CA}$ than under $21 \% \mathrm{O}_{2}$. When quality was evaluated after 21 days, however, storage under $\mathrm{CA}$ at $10 \mathrm{C}$ was not as beneficial as storage in $21 \% \mathrm{O}_{2}$, at $1 \mathrm{C}$. Holding peas in $2.4 \% \mathrm{O}$, for up to 3 weeks at $10 \mathrm{C}$, a higher than recommended storage temperature, maintained better quality than $21 \% \mathrm{O}_{2}$. Increasing the CO, concentration from $0 \%$ to $2.6 \%$ or $4.7 \%$ had no adverse effects on quality and had a beneficial effect in some treatments. Compared with storage in $21 \%$ $\mathrm{O}_{2}$, the appearance of the peas was better, the concentrations of chlorophyll and soluble sugar were maintained at higher levels, and the insoluble solids were decreased in all atmospheres with $2.4 \% \mathrm{O}_{2}$. Appearance and concentrations of chlorophyll, soluble sugars, and proteins were maintained at $1 \mathrm{C}$ regardless of treatments.

Very little information is available on the recommended $\mathrm{CO}$, and $\mathrm{O}_{2}$ levels for controlled atmosphere (CA) storage of the sugar or edible podded pea. Controlled-atmosphere research on unshelled peas showed that color and flavor were maintained under storage at $5 \mathrm{C}$ in $5 \% \mathrm{CO}_{2}$ for 20 days (Tomkins, 1957). Chlorophyll levels of 'Harvester' green beans were retained at $7 \mathrm{C}$ for

Received for publication 22 Oct. 1990. Accepted for publication 6 Aug. 1991. The cost of publishing this paper was defrayed in part by the payment of page charges. Under postal regulations, this paper therefore must be hereby marked advertisement solely to indicate this fact.
14 days in $2 \%$ to $3 \% \mathrm{O}_{2}+5 \%$ to $10 \% \mathrm{CO}$, (Groeschel et al., 1966). Sugars were retained in peas (Miller and Brooks, 1932) and lima beans (Miller and Dowd, 1936) when stored in $42 \% \mathrm{CO}_{2}$ for 1 to 2 days at 15,20 , or $25 \mathrm{C}$. Oxygen at $1 \%$ was more beneficial than elevated $\mathrm{CO}_{2}$ in maintaining the chlorophyll and sugar levels in the outer laminae of Chinese cabbage (Wang, 1983).

In this study we examined the use of CA for the storage of sugar peas at temperatures higher than the recommended OC Hardenburg et al., 1986). Changes in appearance, weight, and concentrations of chlorophyll, total sugars, insoluble solids, and soluble protein were monitored as measures of quality.
Sugar peas (cv. Manoa Sugar) were either hand harvested from local growers near Honolulu, Hawaii, or obtained from commercial sources in Honolulu within 1 day of harvest. Uniform pods free of visual defects were selected and randomly sorted into groups of 25 or 45 pods and placed in $0.4-$ or 1 liter jars. Three jars were used per atmosphere and each experiment was repeated between Mar. and May 1987. The sugar peas were weighed and rated for appearance before and after the storage treatments. There are no industry quality standards for sugar peas; therefore, a subjective index was devised similar to that for lettuce (Kader et al., 1973) with modifications: 9 = green calyx and pod, free from defects and firm; $7=$ green calyx and pod, minor defects, slightly wilted; 5 = slightly brown calyx, green pod, obvious defects on pod, wilted pod; $3=$ brown, shriveled calyx, obvious defects on pod, obvious wilt, slight infection from disease; and 1 = unsalable. Data are presented as percent of initial values because of the high degree of variability among the three experiments.

A flow-through system (Morris, 1969) with flow rates of 20 or 14 liter $\cdot(\mathrm{kg} \cdot \mathrm{hr})^{-1}$ was used at 10 or $1 \mathrm{C}$, respectively. The flow rates were based on respiration rates of garden peas (Tewfik and Scott, 1954). The selected flow rates maintained the $\mathrm{O}_{2}$ and $\mathrm{CO}_{2}$ concentrations within $\pm 0.3 \%$ of the desired values. All gases at $1 \mathrm{C}$ were humidified, while only $\mathrm{N}_{2}$ was humidified at $10 \mathrm{C}$. Daily measurements of $\mathrm{CO}_{2}$ and $\mathrm{O}_{2}$ were made with an infrared $\mathrm{CO}_{2}$ analyzer (Model IR 703, Infrared Industries, Santa Barbara, Calif.) and a paramagnetic oxygen analyzer (Servomes Model 570A, Sybron Boston, Mass.), respectively. Weight loss was calculated from the difference between initial and final weight and expressed as a percentage of the initial fresh weight. Compositional data were adjusted for weight loss. The jars were held at $10 \mathrm{C}$ for 14 and 21 days or at $1 \mathrm{C}$ for 21 days.

Sugars were extracted from pod tissue that had been chopped with a razor blade and mixed. A 2-g sample was placed in $20 \mathrm{ml}$ of cold $95 \%$ ethanol and held at $-16 \mathrm{C}$ for 2 weeks (Paul1 et al., 1984). The supernatant was diluted and soluble sugars assayed colorimetrically (Dubois et al., 1956). Glucose was used as the standard.

For further compositional analyses, three 
Table 1. Effect of reduced $\mathrm{O}_{2}$ and elevated $\mathrm{CO}_{2}$ atmospheres on the appearance and weight loss of sugar peas (Pisum sativum var. saccharatum cv. Manoa Sugar).

\begin{tabular}{|c|c|c|c|c|c|c|c|}
\hline \multicolumn{2}{|c|}{ Storage } & \multicolumn{3}{|c|}{$21 \% \mathrm{O}_{2}$} & \multicolumn{3}{|c|}{$2.4 \% \mathrm{O}_{2}$} \\
\hline \multirow{2}{*}{$\begin{array}{l}\text { Period } \\
\text { (days) }\end{array}$} & \multirow{2}{*}{$\begin{array}{l}\text { Temp } \\
\left({ }^{\circ} \mathrm{C}\right)\end{array}$} & \multicolumn{3}{|c|}{$\% \mathrm{CO}_{2}$} & \multicolumn{3}{|c|}{$\% \mathrm{CO}_{2}$} \\
\hline & & 0 & 2.6 & 4.7 & 0 & 2.6 & 4.7 \\
\hline \multicolumn{8}{|c|}{ Appearance (initial subjective rating $=9)^{z}$} \\
\hline $\begin{array}{l}14 \\
21 \\
21\end{array}$ & $\begin{array}{r}10 \\
10 \\
1\end{array}$ & $\begin{array}{r}97 \mathrm{a} \\
46 \mathrm{~d} \\
100 \mathrm{a}\end{array}$ & $\begin{array}{c}100 \mathrm{a} \\
52 \mathrm{~cd} \\
94 \mathrm{a}\end{array}$ & $\begin{array}{r}100 \mathrm{a} \\
61 \mathrm{c} \\
82 \mathrm{~b}\end{array}$ & $\begin{array}{r}100 \mathrm{a} \\
72 \mathrm{~b} \\
100 \mathrm{a}\end{array}$ & $\begin{array}{l}99 \mathrm{a} \\
77 \mathrm{~b} \\
96 \mathrm{a}\end{array}$ & $\begin{array}{r}100 \mathrm{a} \\
73 \mathrm{~b} \\
82 \mathrm{~b}\end{array}$ \\
\hline \multicolumn{8}{|c|}{ Wt loss (\%) } \\
\hline $\begin{array}{l}14 \\
21 \\
21\end{array}$ & $\begin{array}{r}10 \\
10 \\
1\end{array}$ & $\begin{array}{r}14 \mathrm{a} \\
14 \mathrm{a} \\
1 \mathrm{~d}\end{array}$ & $\begin{array}{l}7 \mathrm{a} \\
6 \mathrm{ab} \\
4 \mathrm{bc}\end{array}$ & $\begin{array}{l}8 \mathrm{a} \\
6 \mathrm{ab} \\
5 \mathrm{~b}\end{array}$ & $\begin{array}{l}4 b c \\
4 b c \\
2 c d\end{array}$ & $\begin{array}{l}4 b c \\
4 b c \\
3 c\end{array}$ & $\begin{array}{l}5 b \\
4 b c \\
4 b c\end{array}$ \\
\hline
\end{tabular}

${ }^{2} D$ ata are the means of the percent of the initial value from three replicates in two experiments. The means within each quality category are separated by Duncan's multiple range test, $P=0.05$.

Table 2. Effect of reduced $\mathrm{O}_{2}$ and elevated $\mathrm{CO}_{2}$ atmospheres on postharvest quality of sugar peas (Pisum sativum var. saccharatum cv. Manoa Sugar).

\begin{tabular}{|c|c|c|c|c|c|c|c|}
\hline \multicolumn{2}{|c|}{ Storage } & \multicolumn{3}{|c|}{$21 \% \mathrm{O}_{2}$} & \multicolumn{3}{|c|}{$2.4 \% \mathrm{O}_{2}$} \\
\hline \multirow{2}{*}{$\begin{array}{l}\text { Period } \\
\text { (days) }\end{array}$} & \multirow{2}{*}{$\begin{array}{c}\text { Temp } \\
\left({ }^{\circ} \mathrm{C}\right)\end{array}$} & \multicolumn{3}{|c|}{$\% \mathrm{CO}_{2}$} & \multicolumn{3}{|c|}{$\% \mathrm{CO}_{2}$} \\
\hline & & 0 & 2.6 & 4.7 & 0 & 2.6 & 4.7 \\
\hline \multicolumn{8}{|c|}{ Chlorophyll (initial value $=95 \mathrm{\mu g}^{\prime} \mathrm{g}^{-1}$ fresh wt) ${ }^{x}$} \\
\hline 14 & 10 & $92 \mathrm{abc}$ & $86 \mathrm{c}$ & $94 \mathrm{ab}$ & $90 \mathrm{bc}$ & $88 \mathrm{bc}$ & $86 \mathrm{c}$ \\
\hline 21 & 10 & $78 \mathrm{c}$ & $91 \mathrm{~b}$ & $88 \mathrm{~b}$ & $91 \mathrm{~b}$ & $85 \mathrm{~b}$ & $101 \mathrm{a}$ \\
\hline 21 & 1 & $115 \mathrm{a}$ & 118 a & $110 \mathrm{a}$ & $112 \mathrm{a}$ & $116 \mathrm{a}$ & $110 \mathrm{a}$ \\
\hline \multicolumn{8}{|c|}{ Total soluble sugars (initial value $=25 \mathrm{mg} \cdot \mathrm{g}^{-1}$ fresh $w t$ ) } \\
\hline 14 & 10 & $115 \mathrm{~d}$ & $119 \mathrm{~d}$ & $123 \mathrm{~cd}$ & $133 \mathrm{~b}$ & $136 \mathrm{~b}$ & $127 \mathrm{c}$ \\
\hline 21 & 10 & $106 \mathrm{e}$ & $102 \mathrm{e}$ & $111 \mathrm{de}$ & $105 \mathrm{e}$ & $117 \mathrm{~d}$ & $119 \mathrm{~d}$ \\
\hline 21 & 1 & $128 \mathrm{c}$ & $119 \mathrm{~d}$ & $117 \mathrm{~d}$ & $116 \mathrm{~d}$ & $126 \mathrm{c}$ & $184 \mathrm{a}$ \\
\hline \multicolumn{8}{|c|}{ Insoluble solids, fiber (initial value $=8.1 \mathrm{mg} \cdot \mathrm{g}^{-1}$ fresh wt) } \\
\hline 14 & 10 & $98 \mathrm{~b}$ & 80 cde & $87 \mathrm{c}$ & $85 \mathrm{~cd}$ & $84 \mathrm{~cd}$ & $75 \mathrm{de}$ \\
\hline 21 & 10 & $112 a$ & 83 cde & $95 \mathrm{~b}$ & 78 cde & 76 cde & $85 \mathrm{~cd}$ \\
\hline 21 & 1 & 81 cde & $73 \mathrm{e}$ & 77 cde & $72 \mathrm{e}$ & 78 cde & 76 cde \\
\hline \multicolumn{8}{|c|}{ Soluble protein (initial value $=10.7 \mathrm{mg} \cdot \mathrm{g}^{-1}$ fresh $w t$ ) } \\
\hline 14 & 10 & $118 \mathrm{ab}$ & $76 \mathrm{~d}$ & $120 \mathrm{ab}$ & $82 \mathrm{~d}$ & $81 \mathrm{~d}$ & $109 \mathrm{bc}$ \\
\hline 21 & 10 & $116 \mathrm{abc}$ & $109 \mathrm{bc}$ & $114 \mathrm{abc}$ & $83 \mathrm{~d}$ & $81 \mathrm{~d}$ & $106 \mathrm{bc}$ \\
\hline 21 & 1 & $119 \mathrm{ab}$ & 124 a & $113 \mathrm{abc}$ & $115 \mathrm{abc}$ & $105 \mathrm{bc}$ & $109 \mathrm{bc}$ \\
\hline
\end{tabular}

2Data are the means of the percent of the initial value from three replicates in two experiments. The means within each quality category are separated by Duncan's multiple range test, $P=0.05$.

samples were taken from each replicate after storage for 2 or 3 weeks, frozen in liquid nitrogen, ground in a coffee grinder, and stored at $-16 \mathrm{C}$ until analyzed. Eighty percent acetone was used to extract chlorophyll from a 2-g sample (Arnon, 1949). Ammonium hydroxide (three to four drops) was added to stabilize the chlorophyll, and the samples were kept in the dark on ice. The supernatant was read at 645 and $663 \mathrm{~nm}$ and the amount of chlorophyll in the sample calculated with the following equation: $\mathrm{C}_{(\mathrm{a}+\mathrm{b})}$ $=\left(20.2 \times \mathrm{A}_{645}\right)+\left(8.02 \times \mathrm{A}_{663}\right)$. The micrograms of chlorophyll per grams fresh weight was calculated by multiplying by the dilution factor. After the chlorophyll was extracted, acetone insoluble solids were determined by drying the residue in a vacuum chamber at room temperature. Soluble proteins were extracted from $1 \mathrm{~g}$ of dried, acetone-washed frozen tissue with $5 \mathrm{ml}$ of 0.1 $\mathrm{NaOH}$ at room temperature. The extract was filtered, diluted, and stored at 1C until measured. The Lowry method (Lowry et al., 1951) was used to determine soluble proteins. Bovine serum albumin was used as a standard.
There were no significant changes in the appearance of sugar peas after 14 days of storage at $10 \mathrm{C}$, regardless of storage regime (Table 1). By 21 days at $10 \mathrm{C}$, there was a significant decrease in the appearance of peas stored in $21 \% \mathrm{O}_{2}$, regardless of $\mathrm{CO}_{2}$ concentration. At 21 days, appearance was better under $2.4 \% \mathrm{O}_{2}$ than under $21 \% \mathrm{O}_{2}$. The appearance was slightly better when $4.7 \%$ $\mathrm{CO}$, was added to $21 \% \mathrm{O}_{2}$, but added $\mathrm{CO}$, had no effect in $2.4 \% \mathrm{O}_{2}$. Pods stored under low $\mathrm{O}_{2}$, were more turgid than those stored in $21 \% \mathrm{O}_{2}$, and they had better color than the controls. After 21 days, peas in all treatments at $1 \mathrm{C}$ had retained $>80 \%$ of their initial appearance ratings. Peas held with $4.7 \%$ $\mathrm{CO}$, at either $\mathrm{O}_{2}$ concentration were lower in quality than those held in $0 \%$ or $2.6 \%$ $\mathrm{CO}_{2}$. It appeared that the addition of $\mathrm{CO}_{2}$ worsened the condition of sugar peas stored at $1 \mathrm{C}$ for 21 days. This detrimental effect of $\mathrm{CO}$, was not observed at $10 \mathrm{C}$ with $2.4 \% \mathrm{O}_{2}$. The decrease in subjective ratings was mainly due to a shriveled appearance of the pods after treatment.

After 14 and 21 days at $10 \mathrm{C}$, weight loss was less under the low $\mathrm{O}_{2}(<6 \%$ loss $)$ than with $21 \% \quad \mathrm{O}_{2}(6 \%$ to $14 \%$ loss) (Table 1). Only the $\mathrm{N}_{2}$ in the mixture was humidified at $10 \mathrm{C}$ to lower the relative humidity and thereby reduce the high levels of fungal growth seen in preliminary experiments. All of the gases were humidified for the experiments conducted at $\mathrm{IC}$, and weight loss was $<5 \%$ under these conditions.

Chlorophyll concentrations were slightly higher after 21 days at $10 \mathrm{C}$ in atmospheres containing $21 \% \mathrm{O}_{2}$ plus $2.6 \%$ or $4.7 \% \mathrm{CO}_{2}$ and $2.4 \% \mathrm{O}_{2}$ plus $4.7 \% \mathrm{CO}_{2}$ than in the other atmospheres (Table 2). For storage periods of $\approx 3$ weeks, the use of high $\mathrm{CO}_{2}$ with $21 \%$ $\mathrm{O}_{2}$ has been shown to maintain greenness in peas (Tomkins, 1957). Chlorophyll levels after 21 days were higher at $1 \mathrm{C}$ than at $10 \mathrm{C}$ for all but the $2.4 \% \mathrm{O}_{2}+4.7 \% \mathrm{CO}_{2}$ treatment, which were similar.

Total soluble sugar levels increased under all storage regimes (Table 2). After 14 days at $10 \mathrm{C}$, soluble sugar concentrations slightly higher than initial ones were found in $2.4 \%$ $\mathrm{O}$ plus $0 \%$ or $2.6 \% \mathrm{CO}_{2}$. Addition of $2.6 \%$ or $4.7 \% \mathrm{CO}_{2}$ to $2.4 \% \mathrm{O}_{2}$ was beneficial at $10 \mathrm{C}$ after 21 days. Addition of $4.7 \% \mathrm{CO}_{2}$ to $11 \% \mathrm{O}_{2}$ had a marginal effect on increasing soluble solids. A statistically significant increase in soluble sugars was noted after 21 days at $1 \mathrm{C}$ under $2.4 \% \mathrm{O}_{2}+4.7 \% \mathrm{CO}_{2}$. Treatment of peas and lima beans with high $\mathrm{CO}$, has been shown to increase sugar levels (Miller and Brooks, 1932; Miller and Dowd, 1936). Low $\mathrm{O}_{2}$ was more beneficial than elevated $\mathrm{CO}_{2}$ in maintaining the sugar levels in the outer laminae of Chinese cabbage (Wang, 1983). Our results indicate that sugar levels increased under all storage treatments, and that the combination of low $\mathrm{O}_{2}$ and high $\mathrm{CO}_{2}$ was slightly better than the other treatments.

The concentration of insoluble solids had decreased under all CA treatments after 14 and 21 days at $10 \mathrm{C}$, except for $21 \% \mathrm{O}_{2}+$ $0.0 \% \mathrm{CO}_{2}$, in which the peas contained significantly more insoluble solids than those of the other treatments. After storage at $1 \mathrm{C}$ for 21 days, the levels of insoluble solids were similar among atmospheres. At this time levels of insoluble solids at $1 \mathrm{C}$ were similar to those found at $10 \mathrm{C}$ under $21 \% \mathrm{O}_{2}+2.6 \%$ $\mathrm{CO}$, and all mixtures with $2.4 \% \mathrm{O}_{2}$.

An increase in soluble proteins is highly correlated with the onset and progression of vegetative senescence (Thimann, 1980). Concentrations of soluble proteins were higher than the initial value in all lots kept at $1 \mathrm{C}$, in most atmospheres with $21 \% \mathrm{O}_{2}$, and in the combination of $2.4 \% \quad \mathrm{O}_{2}+4.7 \% \quad \mathrm{CO}_{2}$ at $10 \mathrm{C}$ (Table 2). Lower levels than found in other treatments were consistently measured in the $2.4 \% \mathrm{O}_{2}$ plus $0 \%$ or $2.6 \% \mathrm{CO}_{2}$ at $10 \mathrm{C}$. Only peas stored in $21 \% \mathrm{O}_{2}+2.6 \%$ $\mathrm{CO}_{2}$ for 14 days at $10 \mathrm{C}$ had similarly low concentrations of soluble protein. This low level, however, had disappeared by 21 days and the concentration of soluble protein was similar to that of peas stored in the other $21 \%$ $\mathrm{O}_{2}$ atmospheres. Singh et al. (1972) found less soluble protein in lettuce stored under CA treatments of $1.5 \% \mathrm{O}_{2}+2.5 \% \mathrm{CO}_{2}$ than other CA treatments or air. 
The minor changes in composition after 14 days of storage suggest that 'Manoa Sugar' peas can be stored for 2 weeks at temperatures that are higher than the recommended OC (Hardenburg et al., 1986) without serious loss of quality. However, texture and fibrousness were not measured. The use of CA storage $\left(2.4 \% \mathrm{O}_{2}\right.$ with or without $2.6 \%$ or $4.7 \% \mathrm{CO}_{2}$ ) further extended the shelf life to 21 days at $10 \mathrm{C}$, but the effect of low $\mathrm{O}_{2}$ was greater than that of high $\mathrm{CO}_{2}$. Storage at temperatures near the recommended $0 \mathrm{C}$ maintains the quality of sugar peas for 21 days. Robinson et al. (1975) found that 'Kelvedon Wonder' peas could be stored for 1.5 to 3 weeks at 1 to $2 \mathrm{C}$.

Our results showed that CA treatments of $2.4 \% \mathrm{O}_{2}$ maintained quality of sugar peas for periods of up to 3 weeks at higher than recommended storage temperatures. Increasing the $\mathrm{CO}$, levels to $2.6 \%$ or $4.7 \%$ had no adverse effects on quality. While CA may not currently be economical on a commercial basis, the use of plastic films may be an economically feasible method to produce beneficial modified atmospheres.

\section{Literature Cited}

Arnon, D.I. 1949. Copper enzymes in isolated chloroplasts. Polyphenoloxidase in Beta vulgaris. Plant Physiol. 24:1-15.

Dubois, M., K.A. Gilles, J.K. Hamilton, P.A Rebers, and F. Smith. 1956. Colorimetric method for determination of sugars and related substances. Anal. Chem. 28:350-356

Groeschel. E.C.. A.I. Nelson. and M.P. Steinberg. 1966. Changes in color and other characteristics of green beans stored in controlled refrigerated atmospheres. J. Food Sci. 3:488 496.

Hardenburg, R.E., A.E. Watada, and C.Y. Wang. 1986. The commercial storage of fruits, vegetables, and florist and nursery stocks. U.S. Dept. Agr. Hdbk. 66, Washington, D.C.

Kader, A., W.J. Lipton, and L.L. Morris. 1973. Systems for scoring quality of harvested lettuce. HortScience 8:408-409.

Lowry, O.H., N.J. Rosebrough, A.L. Farr, and R.J. Randall. 1951. Protein measurement with the folin phenol reagent. J. Biol. Chem. 193:265 215.

Miller, E.V. and C. Brooks. 1932. Effect of carbon dioxide content of storage atmosphere on carbohydrate transformation in certain fruits and vegetables. J. Am. Res. 45:449-459.

Miller, E.V. and O.J. Dowd. 1936. Effect of carbon dioxide on the carbohydrates and acidity of fruits and vegetables in storage. J. Agr. Res. $53: 1-17$

Morris, L.L. 1969. A two-stage, flow-through system for vegetables. Proc. Natl. CA Res Conf., Michigan State Univ. (Hort. Rpt. 9):1316.

Paull, R., N.J. Chen, and J. Deputy. 1984. Litchi growth and compositional changes during fruit development. J. Amer. Soc. Hort. Sci. 109:817821.

Robinson, J.E., K.M. Browne, and W.G. Burton. 1975. Storage characteristics of some vegetables and soft fruits. Ann. Applied Biol. 8:399408.

Singh, B., D.J. Wang, and D.K. Salunkhe. 1972 Controlled atmosphere storage of lettuce. 2. Effects on biochemical composition of leaves. J. Food Sci. 37:52-55.

Tewfik, S. and L.E. Scott. 1954. Respiration of vegetables as affected by postharvest treatment. J. Agr. Chem. 2:415-417.

Thimann, K.V. 1980. The senescence of leaves, p. 85-115. In: K.V. Thimann (ed.). Senescence in plants. CRC Press, Boca Raton, Fla.
Tomkins, R.G. 1957. Peas kept for 20 days in gas storage. The Grower 48(5):226-227.

Wang, C.Y. 1983. Postharvest responses of Chinese cabbage to high $\mathrm{CO}_{2}$ treatment or low $\mathrm{O}_{2}$ storage. J. Amer. Soc. Hort. Sci. 108:125-129.

\title{
Catalase Polymorphism and Inheritance in Peach
}

\author{
Dennis J. Werner \\ Department of Horticultural Science, North Carolina State University, \\ Raleigh, NC 27695-7609
}

Additional index words. allozyme, electrophoresis, Prunus persica

Abstract. Catalase isozymes were examined in a wide range of peach [ Prunus persica (L.) Batsch] cultivars representing historical U.S. cultivars, commercial cultivars from numerous North American breeding programs, and the peach plant introduction (PI) collection. All historical peach cultivars from the United States and those released from commercial breeding programs were fixed for the slow ( Cat 1-2) allele, with the exception of 'Belle of Georgia', 'Honeyglo' nectarine, and various cultivars from the Univ. of Florida breeding program, which possessed $a$ fast-migrating ( Cat 1-1) allele in homozygous or heterozygous state. Polymorphism was revealed in the 51 peach PI clones examined, with allelic frequencies of 0.69 and 0.31 for the $\mathrm{Cat} \mathrm{I}-2$ and $\mathrm{Cat} \mathrm{l}-1$ alleles, respectively. Most PIs that originated directly from China were homozygous Cat $1-1 /$ Cat l-1, while most PI clones introduced from Europe were homozygous Cat 1-2 / Cat l2. Examination of the catalase genotype of cultivars previously proposed as the possible male parent of 'Belle of Georgia' ('Champion', 'Early Crawford', 'Late Crawford', 'Oldmixion Free', and 'Stump-the-World') revealed that none of these cultivars could have been the male parent of 'Belle of Georgia'. Segregation data from various peach crosses was consistent with the hypothesis that catalase polymorphism could be explained by the presence of two alleles at a single locus.

Limited isozyme polymorphism has been reported in peach, despite variability for numerous morphological traits. Previous research has identified polymorphism in six enzyme systems (Arulsekar et al., 1986; Durham et al., 1987; Messeguer et al., 1987; Mowrey et al., 1990). Isozymes are useful as molecular markers in genetic linkage studies; however, polymorphism is a prerequisite for their use in such studies. The objective of this study was to examine a comprehensive collection of peach cultivars and the U.S. Dept. of Agriculture's (USDA) peach PI collection for catalase polymorphism. The inheritance of catalase is also reported.

Numerous cultivars (Table 1) and 51 peach PIs (Table 2) were examined in this survey. Cultivars examined were representative of

Received for publication 14 Feb. 1991. I thank Steve Worthington and Dana Moxley for technical assistance, Bruce Mowrey for developing many of the populations used in this study, and Dick Okie, U.S. Dept. of Agriculture, Byron, Ga.. and Wayne Sherman, Fruit Crops Dept., Univ. of Florida, for providing plant samples. Research supported from funds provided by the North Carolina Agricultural Research Service, Raleigh. The cost of publishing this paper was defrayed in part by the payment of page charges. Under postal regulations, this paper therefore must be hereby marked advertisement solely to indicate this fact. commercial germplasm developed in U.S. breeding programs, with special emphasis placed on cultivars released from the Univ. of Florida; USDA, Byron, Ga.; and North Carolina State Univ. breeding programs. Historical cultivars of North American origin distinct from the germplasm base represented by cultivars originating from North American breeding programs were also examined. Eight seedling populations segregating for catalase were examined to determine the inheritance of catalase.

Fully expanded leaves $\approx 6 \mathrm{~cm}$ from the terminal bud were collected from actively growing shoots of field-grown trees in Summer 1990. Catalase was characterized on lithium borate/Tris.citrate starch gels (Stuber et al., 1988) using previously described electrophoretic procedures (Mowrey et al., 1990), except that the modified stone-fruit extraction buffer of Arulsekar and Parfitt (1986) was used. The extraction buffer was modified by deleting polyethylene glycol, L-cysteine, and $\beta-$ mercaptoethanol. Gels were run for $6 \mathrm{~h}$ at $13 \mathrm{~W}$ of constant power. All cultivars and PIs were characterized twice for catalase using two independent electrophoretic runs. Progeny of seedling populations were characterized only once. Goodness-offit of observed segregations to the appropriate genotypic test ratio was conducted using chi-square analysis. Migration distances were 